\title{
A Foreign Material in the Right Heart for 26 Years Which Was Found During the Coronary Angiography
}

\section{Yıldır Sağ Kalpte Bulunan ve Koroner Anjiyografi Esnasında Saptanan Yabancı Cisim}

Yazışma Adresi/ Correspondence

Dr. Mustafa Yıldız

Kartal Koşuyolu Yüksek İhtisas Eğitim ve Araştırma Hastanesi, Kardiyoloji Kliniği, Denizer Caddesi, Cevizli Kavşağı No: 234846 Cevizli, Kartalistanbul-Türkiye e-posta mustafayilldiz@yahoo.com

\author{
Mustafa Yıldız ${ }^{1}$, Süleyman Karakoyun ${ }^{1}$, Ebuzer Aydın ${ }^{1}$, Mehmet Özkan ${ }^{1}$ \\ ${ }^{1}$ Department of Cardiology, Kosuyolu Heart Center, Kartal, Istanbul, Turkey \\ 1 Kartal Koşuyolu Yüksek Ihtisas Eğitim ve Araştırma Hastanesi, Kardiyoloji Kliniği, İstanbul, Türkiye
}

A 76-year-old male patient who underwent coronary by pass surgery 27 years ago, was admitted to our hospital with angina pectoris. He was performed left and right heart catheterization after one year later from coronary by pass surgery due to an unknown reason. During coronary angiography, in our catheter laboratory, we noticed that there was a foreign material which was extend to right ventricle from right atrium and it seemed like right Judkins catheter on fluoroscopy (Figure 1A). The material (about $8 \mathrm{~cm}$ ), located in the right atrium and ventricle, was confirmed with multislice computerized tomography (Figure 1B). We considered that the material destroyed while performing right heart catheterization via right femoral vein with (most probably) re-use catheter almost 26 years ago. The patient has been taking only $300 \mathrm{mg} /$ day acetilsalisilic acid without any anti-coagulant since that time. We performed real time three-dimensional transesophageal echocardiography to exclude the thrombus due to foreign material and found normal (Figure 1C). After having informed the patient, he was discharged with medical therapy. We found this report interesting to be presented since the foreign material didn't cause any thromboembolic events even though it was huge, in the right heart for a long time and the patient was not under any anticoagulant therapy ${ }^{(1)}$. Also, to our knowledge, this is the first case we demonstrated the foreign material with real time three-dimensional transesophageal echocardiography. 
A Foreign Material in the Right Heart for 26 Years Which Was Found During the Coronary Angiography 26 Yıldır Sağ Kalpte Bulunan ve Koroner Anjiyografi Esnasında Saptanan Yabancı Cisim

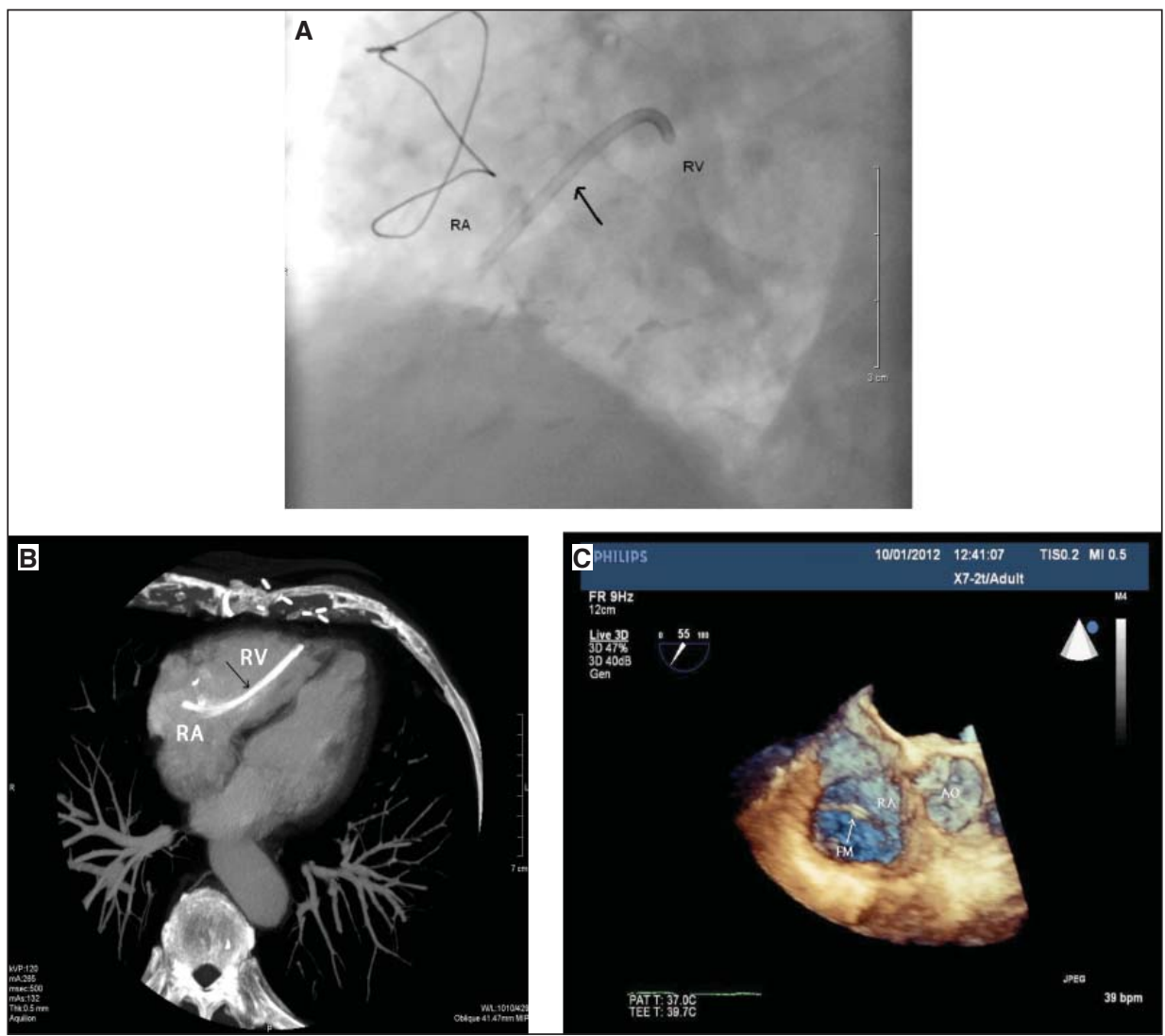

Figure 1. A: A foreign material image in the right heart during coronary angiography (LAO $\left.30^{\circ}\right)$, B: During multislice computerized tomography, C: Real time three-dimensional transesophageal echocardiography showed any thrombus on the foreign material (RA: Right atrium, RV: Right ventricle, Arrow, FM: Foreign material, AO: Aort).

\section{REFERENCE}

1. Motta Leal Filho JM, Carnevale FC, Nasser F, Santos AC, Sousa Junior Wde O, Zurstrassen CE, et al. Endovascular techniques and procedures, methods for removal of intravascular foreign bodies. Rev Bras Cir Cardiovasc 2010;25:202-8. 